\title{
Oxidative Stress, Plant-Derived Antioxidants and Liver
}

R. Gebhardt

\begin{abstract}
There is accumulating evidence that oxidative stress plays a considerable role in the development of liver fibrosis by acting in different cell types and in different signaling pathways. Consequently, antioxidants, particularly those of plant origin, have emerged as potent antifibrotic agents. This review briefly sum-
\end{abstract}

marizes current views of the mechanisms of fibrogenesis and recent findings on the antifibrotic potential of plant-derived antioxidants.

\section{Key words}

Antioxidants · fibrogenesis · flavonoids · hepatic stellate cells · reactive oxygen species

\section{Introduction}

Liver fibrosis and cirrhosis developing in response to chronic hepatocellular injury (Table 1) show general features of a wound repair process [1], [2] characterized by specific cellular reactions that are orchestrated by a set of cytokines and other signaling molecules and finally lead to the excessive deposition of extracellular matrix proteins [2], [3], [4], [5]. As these processes continue, remodelling of the liver architecture is apparent resulting in severe pathophysiological consequences such as liver insufficiency, portal hypertension and hepatic encephalopathy. Although fibrosis and cirrhosis are of high incidence worldwide, therapeutic management of these diseases is still insufficiently based on therapeutic concepts that focus mainly on symptoms rather than on blocking central fibrogenic mechanisms [6], [7], [8]. Recent progress in the understanding of the pathological mechanisms, however, may open new strategies with which to interfere at early steps in the development of these diseases [3], [9], [10].

Oxidative stress has long been known to be involved in the pathogenesis of hepatic fibrosis [1], [11], [12], [13]. In the past, the main focus was placed on the damaging potential of oxygen radi-
Table 1 Natural and experimental causes of liver fibrosis

\begin{tabular}{ll}
\hline $\begin{array}{l}\text { Viral hepatitis (chronic) } \\
\text { Alcohol abuse }\end{array}$ & $\begin{array}{l}\text { Chemicals (carbon tetrachloride, dimethyl- } \\
\text { nitrosamine, stilbestrol, yellow phosphorus) }\end{array}$ \\
\hline Radiation & Drugs (methyldopa) \\
Cholestasis & Diet (choline deficient) \\
(bile duct ligation) & Heterologous serum (pig in rats) \\
Oxidative stress & TGF- $\beta$ transgenic mice
\end{tabular}

cals and other radicals for parenchymal cells (PC) [11], [14]. Thus, oxidative stress and radicals were considered as special primary causes of the disease. Consequently, antioxidants were recommended only in rare occasions [14] and were not recognized as therapeutic drugs with a potentially wide application. With time, it became increasingly evident that oxidative stress is associated with various cellular reactions during the development of fibrosis [15] (and of other pathologies [16]) and, thus, may not only be cause of but also mediator in this process (see below). Despite this fact, the therapeutic potential of antioxidants in fibrosis was not estimated adequately in reviews on traditional and more recent therapeutic approaches [8], [9]. 


\section{Current View of Fibrogenesis}

As illustrated in Fig. 1 our present understanding of the key events in hepatic fibrosis reflects a complex interplay of cells and mediators. Roughly, the pathophysiological process can be divided into three phases [17], the preinflammatory, the inflammatory, and the postinflammatory phase. During the preinflammatory phase complete or minor damage of hepatic parenchymal cells (PC) initiates or facilitates the release of paracrine acting mitogen(s) and catokines that have a dual effect. First, they induce proliferation of hepatic perisinusoidal stellate cells (PSC) [18]. Second, they activate resident macrophages, the Kupffer cells (KC), which, in turn, by releasing a whole spectrum of different cytokines initiate the inflammatory phase [17], [19]. This phase is associated with a number of cellular changes in liver parenchyma. Stimulated by TGF- $\beta$, the prototype of a fibrogenic cytokine, normal PSC transform into a myofibroblast-like phenotype [20], [21]. Other cytokines may participate in this process as well [4], [17], [19], [22], [23], [24]. This transformation is considered a central event, since the resulting myofibroblasts have been shown to contribute in many ways to the excessive deposition of extracellular matrix [22], [25], [26] and to produce several other mediators that further promote the cellular changes in a paracrine and autocrine fashion [19], [27], [28]. Production of such factors may lead to the recruitment of new cells (neutrophils, mast cells, etc.) in liver parenchyma [28], [29], [30]. In addition, the activated KC attract other cell types such as polymorphonuclear leukocytes (PML) and may even potentiate damage of PC via release of proteases, reactive oxygen species (ROS) and toxic cytokines (e.g., TNF- $\alpha$ ) [17], [31]. In general, the inflammatory phase may be characterized as the most aggressive period, maintained in a vicious cycle by various (chronic) exogenous and endogenous signals. Despite the fulminant dynamic of this phase, fibrogenesis is still reversible as obvious from spontaneous regeneration, when primary stimuli are withdrawn [32] or after interference with anti-inflammatory cytokines [4], [19], [33]. In contrast of the detailed view of the pathogenesis, information on the mechanisms leading to (spontaneous) regeneration is relatively sparse as yet. Apoptosis of stellate cells seems to be important [9], [32], [34], [35], but little is known about the regulation of this process [36]. From recent studies, however, it is emergent that signals transmitted through neuronal factors like nerve growth factor [37] or through the peripheral-type benzodiazepine receptor [38] may be involved in this regulation as may be fibronectin-derived antiadhesive peptides [39].

The autocrine stimulation of the myofibroblasts initiated already in the inflammatory phase may be the most important feature of the third, the postinflammatory phase which is characterized by an increasing self-perpetuation of the fibrogenic process [27]. Apparently, cellular reprogramming has reached a degree that is independent of the primary stimuli [40]. One reason for this may be the continuous deposition of extracellular matrix which modulates the environment of the cells and is known to considerable influence gene expression in transformed PSC [17], [41], [42], [43]. Another reason may be changes in the response to cytokines characteristic for the myofibroblast phenotype as found for TGF- $\beta$ signaling [44]. To what extent the pathogenesis is reversible at this point, is still a matter of debate and has to await further elucidation of regenerating mechanisms. When the process continues to develop into cirrhosis, however, the irreversible state is reached undoubtedly.

\section{Fibrogenesis in Alcoholic Fibrosis and Chronic Hepatitis}

Although the principal sequence of events is likely to be similar in fibrosis of different etiology, inflammation may not always be overt as, for instance, in alcoholic fibrosis [45]. There, hypoxia and products of oxidative stress may be more important [46], [47], since enhanced ROS production occurs in response to CYPIIE1-induction by ethanol [48]. However, the pathogenesis of alcoholic liver disease involves additional mechanisms specific to excessive alcohol consumption [49], [50]. In chronic hepatitis C, PSC activation and fibrosis seem to be associated with necroinflammation and a Th1-like response, but independent on viral load [51]. While elimination of hepatitis $C$ virus in responders to interferon therapy led to a deactivation of stellate cells [52], in non-responders $d$-alpha-tocopherol was able to prevent fibrogenesis [53], again favoring oxidative stress as mediator. Apparently, various aspects of the general scheme of fibrogenesis may be emphasized differently depending on the type of primary stimulus, its duration and other circumstances.

\section{Specific Involvement of Oxidative Stress in Fibrogenesis}

ROS may be created by a variety of different mechanisms and usually are under close control by sophisticated cellular detoxification systems (Fig. 2). Within the cascade of events outlined above for fibrogenesis, oxidative stress is enhanced and seems to be involved in many ways. This will be summarized for each of several main liver cell types individually.

\section{Hepatocytes}

On the level of the parenchymal cells, production of ROS may be cause and consequence of cellular damage. For instance, many hepatotoxins (often through metabolism by the cytochrome P450 system [48], [54] lead to increased concentrations of ROS that cannot be handled in a normal way by the protective machinary of the cells [55]. Excessive production of ROS results in lipid peroxidation leading to an increase in highly reactive aldehydic end products, altered signal transduction, modulation of gene expression, alteration of the redox state including decrease of glutathione levels, and induction of apoptosis and necrosis [56], [57], [58]. With respect to fibrogenesis, enhanced rates of lipid peroxidation that surmount those associated with physiological events (e.g., hepatocyte regeneration) seem to be of considerable importance [59]. Thus, additional factors such as the availability of heavy metals, particularly of free iron, may be cofibrogenic by enhancing oxidative stress [13]. However, this may vary for hepatocytes and KC in different types of fibrosis [13]. Under the conditions of high lipid peroxidation, the aldehydes formed (e.g., malondialdehyde and 4-hydroxynonenal) attack various cellular and extracellular proteins in the hepatocytes but also in adjacent cell types [60]. They seem to affect gene expression in adjacent PSC as demonstrated by the induction of matrix components (collagen type I, fibronectin), matrix metalloproteinases and other factors [56], [61], [62], [63], [64], [65]. Fibroblasts could also be a potential target [59], [66].

\section{Kupffer cells}

Similar events from increased lipid peroxidation to induction of apoptosis may act on the level of KC. However, in the case of 


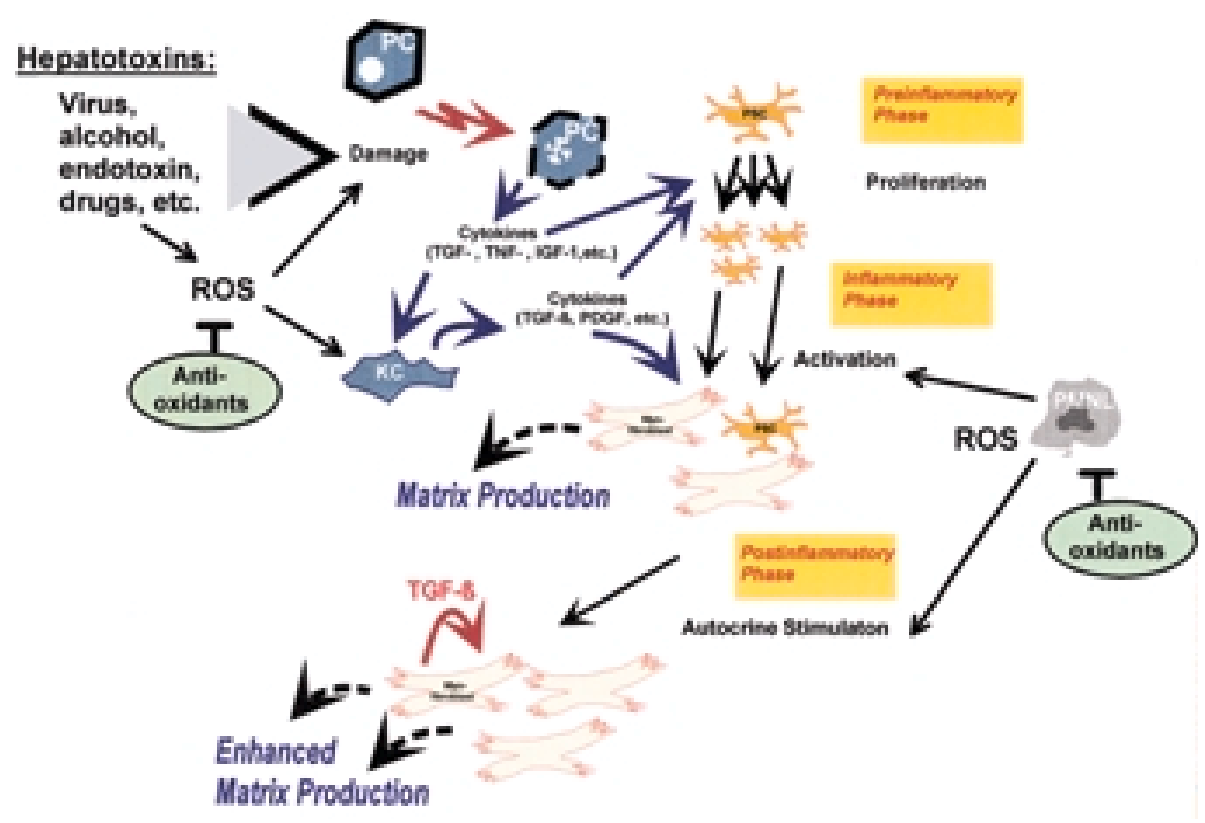

Fig. 1 Key events in hepatic fibrosis. Schematic illustration of key events in fibrogenesis emphasizing the role of reactive oxygen species (ROS) and some cytokines. Possible major sites for intervention by antioxidants are also indicated. KC, Kupffer cells; PC, parenchymal cells; PMNL, polymorphonclear leukocytes; PSC, perisinusoidal stellate cells.

ig. 2 Major reaction of reactive oxygen species (ROS). Schematic illustration of basic mechanisms of the formation, detoxification, and damaging reactions of reactive oxygen species. $\mathrm{Cu}^{++}$, copper, $\mathrm{Fe}^{++}$, iron; HNE, 4-hydroxynonenal; MDA, malon dialdehyde; SOD, superoxide dismutase.

\section{ROS- PRODUCTION}

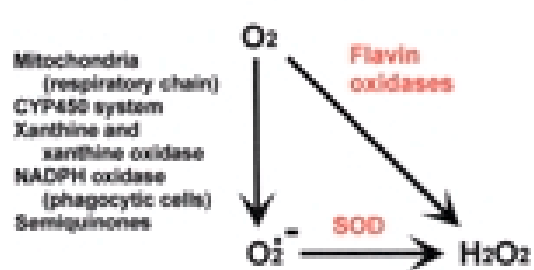

\section{DEFENSE}

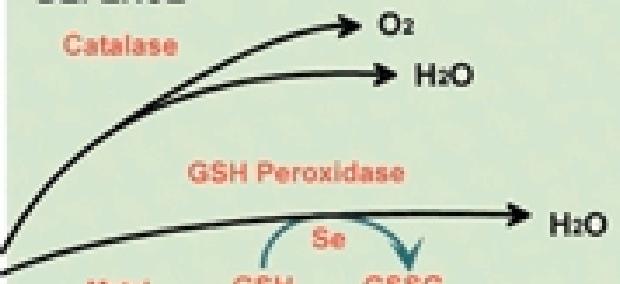

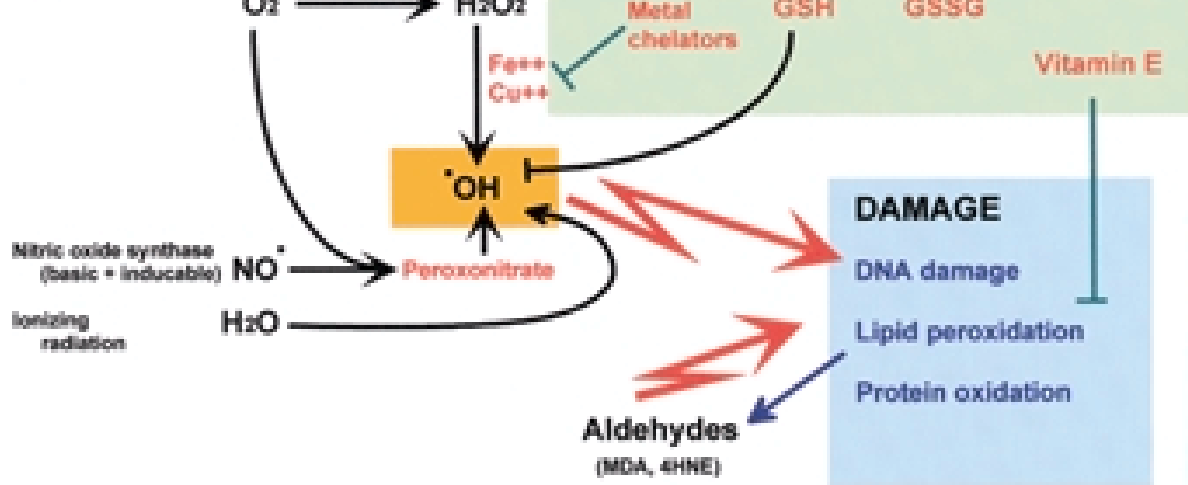

these cells excessive production of, rather than ultimate injury by, ROS seems to prevail in their activated state. Thus, phagocytic activity is accompanied by increased formation of toxic oxygen metabolites and other radical species such as NO [24], [67]. Similar products may be generated by PML [24]. These products are released into the extracellular space and may attack other cells in the vicinity. Interestingly, however, NO has been found to act as a scavenger of ROS in vitro inhibiting PSC proliferation [68]. Thus, the precise role of peroxonitrate formed from NO (see Fig. 2) remains to be clarified.

\section{Perisinusoidal stellate cells}

Besides the parenchymal cells and macrophages, PSC may be attacked by liberated ROS. Due to their central role in fibrogenesis, these cells may represent the most important cellular target. However, although ROS may promote transformation of PSC [69], such molecules may also be mediators of transformation by other stimuli, e.g., TGF- $\alpha$ and collagen type I [17]. Apparently, there is considerable cross-talk between ROS and various signaling pathways [70], [71] (see below). Moreover, ROS seem to be involved in further regulating and influencing many cellular events once the myofibroblast-like phenotype has been established. Thus, ROS have been shown to directly affect the synthesis of monocyte chemoattractant protein I [72] and connective tissue growth factor (CTGF) [73]. It is likely that other proteins produced by PSC (myofibroblasts that are related to fibrogenesis are directly induced as well. On the other hand, the fibrogenic effect of oxidative stress induced by ferric nitrotriacetate in cultured PSC seems to be mediated through induction of the $\mathrm{Na}^{+} / \mathrm{H}^{+}$exchanger [74]. The importance of the $\mathrm{NA}^{+} / \mathrm{H}^{+}$exchange which can also be induced by other factors like PDGF and IGF-1 [75] for the fibrogenic process has recently been stressed in vitro and in vivo [76]. In other models, NF- $\kappa \mathrm{B}$ and $\mathrm{c}$ myb seem to be essential mediators [3], [77], indicating again that ROS and other radicals have to interfere with certain signaling pathways, in order to exert their effects. Indeed, activation of $\mathrm{NF}-\kappa \mathrm{B}$ might play a potent 
role in hepatic injury and fibrosis [78] through activation of PSC [79]. Although NF- $\kappa \mathrm{B}$ is believed to mediate a general antioxidant cellular response [80], its activation is subject to complex control opening the possibility for alternative functional consequences. Thus, it was reported that NF- $\kappa \mathrm{B}$ may be involved in apoptosis rather than proliferation and acitivation of HSC in culture [81], [82]. Moreover, the distal effects of this transcription factor seem to depend on the cellular background [83], and, in particular, on the timing of activation in relation to other signals [84]. Therefore, it is hard to predict whether acitivation of NF- $\kappa$ B will result in cell survival, proliferation, apoptosis or another fate.

As indicated above, aldehydes produced in response to oxidative stress through lipid peroxidation such as 4-hydroxy-2,3-alkenals (e.g., HNE) may play an additional role as mediators [85] both in PSC as well as other cells (for review see [3], [60]. Apparently, transformed PSC are less sensitive to toxic effects of these aldehydes than normal PSC [86]. This seems to be due to a higher rate of metabolism [86] although the level of GSTs which detoxify HNE is decreased [87].

\section{Correspondence of in vitro and in vivo Results}

There is still some uncertainty whether the sequence of events outlined above or their extent is comparable in vivo and in vitro. For instance, this has been questioned with respect to cellular glutathione [88] and the site or temporal pattern of the production of superoxide radicals [89]. Furthermore, modulation of glutathione content may not have easily predictable effects on the function of stellate cells [90]. The context in which these parameters are tested, however, seems to be of considerable influence. It is also possible that the general scheme may vary to some extent depending on the specific cause of fibrosis. Thus, it was doubted that PSC are subject to oxidative stress during ironinduced fibrogenesis in rodents [13]. On the other hand, the level of oxidative stress rather than cytokines seems to be responsible for the progression of the activation of PSC during $\mathrm{CCl}_{4}$-induced fibrogenesis [91]. In this respect it is of interest that the glutathione level can discriminate between oxidative stress and TGF$\beta$ signaling in activated PSC [92].

\section{Therapeutic Potential of Plant-Derived Antioxidants in Liver Fibrosis}

For a long time, the therapeutic potential of antioxidants with respect to fibrosis was realized only marginally [3], [6], [7], [8]. In the last few years, however, a number of studies has dramatically changed this situation [3], [93] placing oxidative stress and the antifibrotic efficacy of antioxidants into focus. Even traditional drugs such as pentoxifylline [94], as well-known phosphodiesterase inhibitor, were unexpectedly found to block PSC activation by interfering with the oxidative stress cascade suggesting new mechanisms for their antifibrotic activity.

\section{Antifibrotic efficiency - in vivo studies}

Accumulative evidence for the effectiveness against fibrosis is now available for several plant-derived antioxidants. Silymarin, the active principle from Carduus marianus L., proved to be antifibrogenic in humans [95], [96] and in a rat fibrosis model [97], [98] where it led to a reduction of hepatic collagen accumulation by more than $35 \%$. It is well known that silymarin and its component silibinin have potent antioxidant activity [99], [100]. Likewise, in a bile duct ligation model, the antifibrotic influence of extracts from Stephania tetrandra and Polygonum aviculare [101], [102] was described, although the active compounds have not yet been identified. In the same experimental model quercetin was found to ameliorate liver damage [103]. Furthermore, antioxidants from the herbal medicine Sho-saiko-to (e.g., baicalein, baicalin and wogonin) were recently found to act antifibrogenic in different animal models, namely choline-deficient L-amino acid-defined diet [104] and fibrosis induced by pig serum [105] or dimethylnitrosamine [105], [106]. Sho-saiko-to had already been known for beneficial effects in patients with chronic active hepatitis [107] and may have an even broader range of potential applications [108]. Also, antioxidants in red wine have long been suspected of exerting antifibrotic effects [50]. Likewise, diosmin was found in vivo to reduce fibrosis associated with edema [139]. These promising reports on plant-derived antioxidants are complemented by other recent findings that polyenylphosphatidylcholine and vitamin E were also effective as antifibrogenic drugs in alcohol-induced fibrosis in the baboon [109] or in carbon tetrachloride-induced liver cirrhosis [14]. Thus, there is no doubt that plant-derived antioxidants represent valuable antifibrotic drugs.

However, what may render these compounds (particularly the flavonoids) so efficient may not be their antioxidative potential alone. This is apparent from reports comparing different antioxidant vitamins ( $\mathrm{C}$ and $\mathrm{E}$ ), selenium and antioxidants from Nigella sativa in $\mathrm{CCl}_{4}$-induced liver fibrosis in rabbits [110]. In this model, Nigella sativa proved to be effective, while vitamin C was not. Concerning vitamin E and selenium results were less promising [110] than in a similar rat fibrosis model [14]. Using this latter model, hepatoprotective effects of other plant extracts from Emblica officinalis (syn. Phyllanthus embilca L.) and Artemisia iwayomogi were found [111], [112] that may only partially involve antioxidant functions. Olive oil in contrast to sunflower, corn or fish oil was also protective against $\mathrm{CCL}_{4}$-induced fibrosis [113].

\section{Possible mechanisms - in vitro studies}

Although the efficacy of antifibrotic agents can best be demonstrated by in vivo studies, mechanistic details of this activity that can be derived from these studies, however, are sparse. Therefore, many in vitro studies with plant extracts, less complex fractions or isolated compounds were performed. Obviously, the antioxidative activity was considered first. In most of the cases cited above, the antioxidants were polyphenols, flavonoids or structurally related compounds [95], [105], [114] that are known as strong antioxidants [115], [116], [117]. As pointed out above, many points of interference of antioxidants with single steps in the fibrogenic process seem possible. Central points seem to be $\mathrm{NF}-\kappa \mathrm{B}, \mathrm{bcl}-\mathrm{x}_{\mathrm{L}}$ and $\mathrm{c}-\mathrm{myb}$ which are upregulated in acitivated PSC [82]. Indeed, silymarin and silibinin inhibit NF- $\kappa$ B activation [83] and seem to retard PSC activation [118] (R. Gebhardt, G. Buniatian, unpublished results). Likewise, trans-resveratrol (from grapes), a strong antioxidant, was found to deactivate the myofibroblast phenotype [119]. Another target may be the induction of CTGF by ROS such as hydrogen peroxide [73]. In general, antioxidant such as baicalin, beicalein, quercetin, apigenin and transresveratrol were shown to interfere with fibrogenic functions of PSC and KC in vitro [105], [114], [118], [119], [120], [121]. 
Concerning flavonoids, it is known that they exert a variety of other effects besides acting as antioxidants. In particular, they are inhibitors of different protein kinases [122], [123], [124] and other kinases involved in signal transduction [125], which they inhibit with different potency. As a result, they may interact with intracellular signaling as has been demonstrated recently for luteolin in cultured hepatocytes [126]. Furthermore, flavonoids are known to interrupt the cell cycle at different points [127], [128]. Accordingly, proliferation of PSC usually associated with the fibrogenic process in vivo was effectively inhibited in vitro by baicalein, the major flavonoid in Sho-saiko-to [129]. A similar function was described for trans-resveratrol which shows some structural similarity to flavonoids [119]. Since protein kinases, in particular stress-activated protein kinases, also play a role in the activation of PSC [130] as well as other cell types [131], such inhibitory effects of flavonoids may be of significance for interrupting the pathogenic process in various different ways rendering these natural compounds particularly interesting for therapeutic use. It remains a challenge for the future to unravel the definitive antifibrotic potential of flavonoids and to elucidate whether there is any synergistic influence between the antioxidative functions and the inhibitory effects on kinases, transporters and other proteins in the prevention of hepatic fibrosis.

\section{Bioavailability, biotransformation and responsiveness}

An issue of particular concern linking in vivo and in vitro studies is the question of bioavailability of genuine compounds on administration of plant extracts or complex fractions. Concerning silymarin and silipide (lipophilic silybin-phosphatidylcholine complex), detailed comparative studies on solubility and pharmacokinetics in animals and patients with extrahepatic biliary obstruction or cholecystectomy have been performed [132], [133], [134], [135]. These studies revealed the rapid availability in serum and bile of silybin (particularly from silipide) in free and conjugated form, but also of silydianin, silycristin and isosilybin. Studies on the bioavailability of baicalin in rats revealed that it is mainly absorbed as the aglycone after hydrolysis by the intestinal micoflora and is reconjugated in intestine and liver [136]. Similar results were reported by Li and coworkers for baicalin and other flavonoids from Sho-saiko-to [137]. Interestingly, these authors demonstrated a delayed excretion of the flavonoids after administration of Sho-saiko-to compared to isolated components [137] indicating an enhanced efficacy of the flavonoids as part of a complex herbal medicine. Although these studies consistently demonstrate the bioavailability of the flavonoids, two aspects deserve further investigation. First, it remains uncertain which molecules (aglycones, conjugates or degradation products) are responsible for the biological effects. Regarding quercetin, for instance, it was shown that some metabolic products (e.g., 3,4-dihydroxytoluene) were almost as efficient as the flavone itself with respect to the antioxidative function as well as the inhibition of metabolic pathways [138]. Thus, biotransformation and breakdown do not necessarily lead to inactivation. Second, patients might be divided into responders (showing high serum levels) and non-responders [137]. The basis for these interindividual differences is not yet known, but may be due to differences in metabolism by the intestinal microflora, in the extent of absorption, and in biotransformation and excretion. Since such question are of considerable importance, if herbal medicines shall be used effectively, these aspects should be investigated in more detail.

\section{Conclusions}

As demonstrated by recent studies in vivo and in vitro, plant antioxidants, particularly flavonoids, show a remarkable potency to block liver fibrogenesis of different etiology. Since the few examples studied so far have just opened a wide horizon, it is worth to screen other plant extracts and natural compounds in appropriate model systems and to look for further compounds combining antioxidative properties with other effector functions. Such studies may lead to new drugs particularly suited and specifically tailored to block liver fibrosis at early steps of pathogenesis. On the basis of preliminary experimental results, it may be expected that such drugs are suitable also for preventive care and for supporting the endogenous regenerating capacity of the liver, once fibrosis has already developed.

Publication of this article was sponsered by Redinomedica AG, Munich.

\section{References}

1 Bissell DM. Hepatic fibrosis as wound repair: a progress report. J. Gastroenterol 1998; 33: 295 - 302

2 Eickelberg O. Endless healing: TGF- $\beta$, SMADs, and fibrosis. FEBS Lett. 2001; 506: $11-4$

3 Li D, Friedman SL. Liver fibrogenensis and the role of hepatic stellate cells: New insights and prospects for therapy. J. Gastroenterol Hepatol 1999; 14: 618-33

4 Gressner AM, Bachem MG. Cellular communications and cell-matrix interactions in the pathogenesis of fibroproliferative disease: liver fibrosis as a paradigm. Ann Biol Clin 1994; 52: 205 - 26

5 Alcolado R, Arthur MJ, Iredale JP. Pathogenesis of liver fibrosis. Clin Sci 1997; 92: $103-12$

6 Chojkier M, Brenner DA. Therapeutic strategies for hepatic fibrosis. Hepatology 1988; 8: 176-82

7 Wu J, Danielsson A. Inhibition of hepatic fibrogenesis: a review of pharmacologic candidates. Scand J Gastroenterol 1994; 29: 385-91

8 Franklin TJ. Current approaches to the therapy of fibrotic diseases. Biochem Pharmacol 1995; 49: 267 - 73

9 Cales P. Apoptosis and liver fibrosis: antifibrotic strategies. Biomed Pharmacother 1998; 52: 259-63

10 Lieber CS. Prevention and teatment of liver fibrosis based on pathogenesis. Alcohol Clin Exp Res 1999; 23: $944-9$

11 Hartmann F, Dölle W. Aetilogy and pathogenesis of liver cirrhosischemicals. In: Boyer JL, Binachi L (eds.). Liver Cirrhosis, MTP Press, Lancaster: 1987: pp. 139-45

12 Arthur MJ. Iron, oxidative stress and liver fibrosis. J Gastroenterol Hepatol 1996; 11: 124-9

13 Pietrangelo A. Iron, oxidative stress and liver fibrosis. J Hepatol 1998; 28: $8-13$

14 Parola M, Leonarduzzi G, Biasi F, Albano E, Biocca ME, Poli G, Dianzani MU. Vitamin E dietary supplementation protects against carbon tetrachloride-induced chronic liver damage and cirrhosis. Hepatology 1992; 16: 1014-21

15 Poli G. Pathogenesis of liver fibrosis: role of oxidative stress. Mol Aspects Med 2000; 21: 49-98

16 Toyokuni S. Reactive oxygen species-induced molecular damage and its application in pathology. Pathol Int 1999; 49: 91 - 102

17 Gressner AM. Transdifferentiation of hepatic stellate (Ito cells) to myofibroblasts: a key event in hepatic fibrogenesis. Kidney Intern 1996; 49: 39-45

18 Gressner AM, Lotfi S, Gressner G, Lahme B. Identification and partial characterization of a hepatocyte-derived factor promoting proliferation of cultured fat storing cells (parasinusoidal lipocytes). Hepatalogy 1992; 16: 1250-66

19 Simpson KJ, Lukas NW, Colletti L, Strieter RM, Kunkel SL. Cytokines and the liver. J Hepatol 1997; 27: 1120-32

20 Bedossa P, Paradis V. Transforming growth factor beta (TGF-beta): a key role in liver fibrosis. J Hepatol 1995; 22: 37-42 
21 Hellerbrand C, Stefanovic B, Giordano F, Burchardt ER, Brenner DA. The role of TGFbeta 1 in initiating hepatic stellate cell acitivation in vivo. J Hepatol 1999; 30: 77-87

22 Kawada N. The hepatic perisinusoidal stellate cell. Histol Histopathol 1997; $12: 1069-80$

23 Tsukamoto H. Cytokine regulation of hepatic stellate cells in liver fibrosis. Alcohol Clin Exp Res 1999; 23: 911 -6

24 Maher JJ. Leukocytes as modulators of stellate cell activation. Alcohol Clin Exp Res 1999; 23: 917 -21

25 Bissel DM. Lipocyte activation and hepatic fibrosis. Gastroenterology 1992; 102: $1803-5$

26 Casini A, Pinzani M, Milani S, Grappone C, Galli G, Jezequel AM et al. Regulation of extracellular matrix synthesis by transforming growth factor $\beta 1$ inhuman fat-storing cells. Gastroenterology 1993; 105 245-53

27 Bachem MG, Meyer DM, Melchior R, Sell KM, Gressner AM. Activation of rat liver perisinusoidal lipocytes by transforming growth factors derived from myofibroblast-like cells - A potential mechanism of self perpetuation in liver fibrogenesis. J Clin Invest 1992; 89: 19-27

28 Sprenger H, Kaufmann A, Garn H, Lahme B, Gemsa D, Gressner AM. Differential expression of monocyte chemotatic protein-1 (MCP-1) in transforming rat hepatic stellate cells. J Hepatol 1999; 30: 88-94

29 Maher JJ, Lozier JS, Scott MK. Rat hepatic stellate cells produce cytokine-induced neutrophil chemoattractant in culture and in vivo. Am J Physiol 1998; 275: G847-53

30 Gaca MD, Pickering JA, Arthur MJ, Benyon RC. Human and rat hepatic stellate cells produce stem cell factor: a possible mechanism for mast cell recruitment in liver fibrosis. J Hepatol 1999; 30: 850-8

31 Gebhardt R, Hartung T. Cokulturen in der in vitro Toxikologie. Biospektrum 1996; 2: 36-9

32 Iredale JP, Benyon RC, Pickering J, McCullen M, Northrop M, Pawley S, Hovell C, Arthur MJ. Mechanisms of spontaneous resolution of rat liver fibrosis. Hepatic stellate cell apoptosis and reduced hepatic expression of metalloproteinase inhibitors. J Clin Invest 1998; 102: 538-49

33 Tilg H. New insights into the mechanisms of interferon alpha. Gastroenterology 1997; 112: $1017-21$

34 Saile B, Knittel T, Matthes N, Schott P, Ramadori G. CD95/CD95Lmediated apoptosis of the hepatic stellate cell. A mechanism terminating uncontrolled hepatic stellate cell proliferation during hepatic tissue repair. Am J Pathol 1997; 151: 265 - 72

35 Rippe RA. Live or death: the fate of the hapatic stellate cell following hepatic injury. Heaptology 1998; 27: 1447-8

36 Gressner AM. The up-and-down of hepatic stellate cells in tissue injury: apoptosis restores cellular homeostasis. Gastroenterology 2001; 120: $1285-8$

37 Trim N, Morgan S, Evans M, Issa R, Fine D, Afford S, Wilkins B, Iredale J. Hepatic stellate cells express the low affinity nerve growth factor receptor p75 and undergo apoptosis in response to nerve growth factor stimulation. Am J Pathol 2000; 156: 1235 - 43

38 Fischer R, Schmitt M, Bode JG, Häussinger D. Expression of the peripheral-type bezodiazepine receptor and apoptosis induction in hepatic stellate cells. Gastroenterology 2001; 120: $1212-26$

39 Kato R, Kamiya S, Ueki M, Yajima H, Ishii T, Nakamura H, Katayama T, Fukai F. The fibronectin-derived antiadhesive peptides suppress the myofibroblast conversion of rat hepatic stellate cells. Exp Cell Res 2001; 265: 54-63

40 Kim Y, Ratziu V, Choi SG, Lalazar A, Theiss G, Dang Q Kim SJ, Friedman SL. Transcriptional activation of transforming growth factor beta1 and its receptors by the Kruppel-like factor Zf9/core promoter-binding protein and Sp1. Potential mechanisms for autocrine fibrogenesis in response to injury. J Biol Chem 1998; 273: 33750-8

41 Lee K, Buck M, Houglum K, Chojkier M. Activation of hepatic stellate cells by TGF-alpha and collagen type I is mediated by oxidative stress through c-myb expression. J Clin Invest 1995; 96: 2461 -8

42 Iwamoto $\mathrm{H}$, Sakai $\mathrm{H}$, Nawata $\mathrm{H}$. Inhibition of integrin signaling with ARG-Gly-Asp motifs in rat hepatic stellate cells. J Hepatol 1998; 29: $752-9$

43 Sato M, Kojima N, Miura M, Imai K, Senoo H. Induction of cellular processes containing collagenase and retinoid by integrin-binding to interstitial collagen in hepatic stellate cell culture. Cell Biol Int 1998 22: $115-25$

44 Doooley S, Delvoux B, Lahme B, Mangasser-Stephan K, Gressen AM. Modulation of transforming growth factor beta response and signaling during transdifferentiation of rat hepatic stellate cells to myofibroblasts. Hepatology 2000; 31: 1094-106
45 Nakano M, Worner TM, Lieber CS. Perivenular fibrosis in alcoholic liver injury: ultrastructure and histologic progression. Gastroenterology 1982; 83: 777-85

46 Friedman SL. Stellate cell activation in alcoholic fibrosis - an overview. Alcohol Clin Exp Res 1999; 23: $904-10$

47 Albano E, French SW, Ingelman-Sundberg M. Hydroxyethyl radicals in ethanol hepatoxicity. Front Biosci 1999; 4: D533-40

48 Mari M, Wu D, Nieto N, Cederbaum Al. CYP2E1-dependent toxicity and up-regulation of antioxidant genes. J Biomed Sci 2001; 8: 52-8

49 Crabb DW. Pathogenesis of alcoholic liver disease: newer mechanisms of injury. Keio J Med 1999; 48: 184-8

50 Svegliati-Baroni G, Jezequel AM, Orlandi F. Wine: risk factors for liver disease and antifibrotic compounds. Drugs Exp Clin Res 1999; 25 : $143-5$

51 Baroni GS, Pastorelli A, Manzin A, Benedetti A, Marucci L, Solforosi L, Di Sario A, Brunelli E, Orlandi F, Clementi M, Macarri G. Hepatic stellate cell activation and liver fibrosis are associated with necroinflammatory injury and Th1-like response in chronic hepatitis C. Liver 1999; 19: $212-9$

52 Sakaida I, Nagatomi A, Hironaka K, Uchida K, Okita K. Quantitative analysis of liver fibrosis and stellate cell changes in patients with chronic hepatitis $\mathrm{C}$ after interferon therapy. Am J Gastroenterol 1999; 94: 489-96

53 Houglum K, Venkataramani A, Lyche K, Chojkier M. A pilot study of the effects of $d$-alpha-tocopherol on hepatic stellate cell activation in chronic hepatitis C. Gastroenterology 1997; 113: 1069-73

54 Gebhardt R. Metabolic zonation of the liver: regulation and implications for liver function. Pharmac Ther 1992; 53: 275-354

55 Inoue M. Protective mechanisms against reactive oxygen species. In: Arias IM, Bojer JL, Fausto N, Jacoby WB, Schachter D, Shafritz DA, editors. The Liver. Biology and Pathobiology, New York: Raven Press 1994: pp. 443-59

56 Comporti M. Biology of disease. Lipid peroxidation and cellular damage in toxic liver injury. Lab Invest 1985; 53: 599-25

57 Dalton TP, Shertzer HG, Puga A. Regulation of gene expression by reactive oxygen. Annu Rev Pharmacol Toxicol 1999; 39: 67-101

58 Kowaltowski AJ, Vercesi AE. Mitochondrial damage induced by conditions of oxidative stress. Free Radic Biol Med 1999; 26: 463 - 71

59 Hernandez-Munos R, Diaz-Munos M, Lopez V, Lopez-Barrera F, Yanez L, Vidrio S, Aranda-Fraustro A, de Sanchez V. Balance between oxidative damage and proliferative potential in an experimental rat model of $\mathrm{CCl}_{4}$-induced cirrhosis: protective role of adenosine administration. Hepatology 1997; 26: 1100-10

60 Parola M, Robino G, Dianzani MU. 4-Hydroxy-2,3-alkenals as molecular mediators of oxidative stress in the pathogenesis of liver fibrosis. Int J Mol Med 1999; 4: 425-32

61 Houglum K, Filip M, Witztum JL, Chojkier M. Malondialdehyde and 4 hydroxynonenal protein adducts in plasma and liver of rats with iron overload. J Clin Invest 1990; 86: 1991 - 8

62 Casini A, Cunningham M, Rojkind M, Liber CS. Acetaldehyde increases procollagen type I and fibronectin gene transcription in cultured rat fat-storing cells through a protein synthesis-dependent mechanisms. Hepatology 1991; 13: 758-65

63 Casini A, Galli G, Solzeno R, Ceni E, Franceschelli F, Rotella CM, Surrenti $C$. Acetaldehyde induces $\mathrm{c}$-fos and c-jun proto-onogenesis in fat-storing cell cultures through protein kinase c activation. Alcohol Alcohol 1994; 29: $303-14$

${ }^{64}$ Holstege A, Bedossa P, Poynard T, Kollinger M, Chaput JC, Houglum K, Chojkier M. Acetaldehyde-modified epitopes in liver biopsy specimens of alcoholic and nonalcoholic patients; localization and association with progression of liver fibrosis. Hepatology 1994; 19: 367-74

65 Svegliati Baroni G, Ridolfi F, Di Sario A, Saccomanno S, Bendia E, Benedetti A, Greenwel P. Intracellular signaling pathways involved in acetaldehyde-induced collagen and fibronectin gene expression in human hepatic stellate cells. Hepatology 2001; 33: 1130-40

66 Brenner DA, Chojkier M. Acetaldehyde stimulates collagen and noncollagen protein production by human fibroblasts. J Biol Chem 1987; 262: $17690-5$

67 Casini A, Ceni E, Salzano R, Biondi P, Parola M, Galli A, Foschi M, Caligiuri A, Pinzani M, Surrenti C. Neutrophil-derived superoxide anion induces lipid peroxidation and stimulates collagen synthesis in human hepatic stellate cells: role of nitric oxide. Hepatology 1997; 25: $361-7$

68 Svegliati Baroni G, Saccomanno S, van Goor H, Jansen P, Benedetti A Moshage H. Involvement of reactive oxygen species and nitric oxide radicals in activation and proliferation of rat hepatic stellate cells. Liver 2001; $21: 1-12$ 
69 Svegliati Baroni G, D’Ambrosio L, Ferretti G, Casini A, Di Sario A, Salzano R, Ridolfi F, Saccomanno S, Jezequel AM, Benedetti A. Fibrogenic effect of oxidative stress on rat hepatic stellate cells. Hepatology 1998; 27: 720-6

70 Britton RS, Bacon BR. Intracellular signaling pathways in stellate cell activation. Alcohol Clin Exp Res 1999; 23: 922 - 5

71 Lang A, Brenner DA. Gene regulation in hepatic stellate cell. Ital J Gastroenterol Hepatol 1999; 31: $173-9$

72 Xu Y, Rojkind M, Czaja MJ. Regulation of monocyte chemoattractant protein 1 by cytokines and oxygen free radicals in rat hepatic fat storing cells. Gastroenterology 1996; 110: 1870 - 7

73 Park SK, Kim J, Seomun Y, Choi J, Kim DH, Han IO, Lee EH, Chung SK, Joo CK. Hydrogen peroxide is a novel inducer of connective tissue growth factor. Biochem Biophys Res Commun 2001; 284: 966 - 71

74 Svegliati-Baroni G, Di Sario A, Casini A, Feretti G, D’Ambrosio L, Ridolfi F, Bolognini L, Salzano R, Orlandi F, Benedetti A. The $\mathrm{Na}^{+} / \mathrm{H}^{+}$exchanger modulates the fibrogenic effect of oxidative stress in rat hepatic stellate cells. J Hepatol 1999; 30: 868 - 75

75 Di Sario A, Svegliati Baroni G, Bendia E, Ridolfi F, Saccomanno S, Ugili L, Trozzi L, Marzioni M, Jezequel AM, Macarri G, Benedetti A. Intracellular $\mathrm{pH}$ regulation and $\mathrm{Na}^{+} / \mathrm{H}^{+}$exchange activity in human hepatic stellate cells: effect of platelet-derived growth factor, insulin-like growth factor 1 and insulin. J Hepatol 2001; 34: $378-85$

76 Benedetti A, Di Sario A, Casinin A, Ridolfi F, Bendia E, Pigini P, Tonnini C, D’Ambrosio L, Feliciangeli G, Macarri G, Svegliati Baroni G. Inhibition of the $\mathrm{Na}^{+} / \mathrm{H}^{+}$exchanger reduces rat hepatic stellate cell activity and liver fibrosis: an in vitro and in vivo study. Gastroenterology 2001; 120: $545-56$

77 Lee KS, Cottam HB, Houglum K, Wasson DB, Carson D, Chojkier M. Pentoxifylline blocks hepatic stellate cells activation independently of phosphodiesterase inhibitory activity. Am J Physiol 1997; 273 . G1094-100

$78 \mathrm{Wu}$ J, Zern MA. NF-kappa B, lipososomes and pathogenesis of hepatic injury and fibrosis. Front Biosci 1999; 4: D520-7

79 Lee KS, Lee SJ, Park HJ, Chung JP, Han KH, Chon CY, Lee SI, Moon YM. Oxidative stress effect on the activation of hepatic stellate cells. Yonsei Med J 2001; 42: $1-8$

$80 \mathrm{Li} \mathrm{N}$, Karin M. Is NF-kappaB the sensor of oxidative stress?. FASEB 1999; $13: 1137-43$

81 Lang A, Schoonhoven R, Tuvia S, Brenner DA, Rippe RA. Nuclear factor $\mathrm{kB}$ in proliferation, activation and apoptosis in rat hepatic stellate cells. J Hepatol 2000; 33: 49 - 58

82 Saile B, Matthes N, El Armouche H, Neubauer K, Ramadori G. The bcl, $\mathrm{NF}-\kappa \mathrm{B}$ and $\mathrm{p} 53 / \mathrm{p} 21^{\mathrm{WAF} 1}$ systems are involved in spontaneous apoptosis and in the anti-apoptotic effect of TGF- $\beta$ or TNF-alpha on activated hepatic stellate cells. Eur J Cell Biol 2001; 80: 554-61

83 Saliou C, Rihn B, Cillard J, Okamoto T, Packer L. Selective inhibition of $\mathrm{NF}-\kappa \mathrm{B}$ activation by the flavonoid hepatoprotector silymarin in HepG2. Evidence of different activating pathways. FEBS Lett 1998 440: $8-12$

84 Foo SY, Nolan GP. NF- $\kappa$ B to the rescue. RELs, apoptosis and cellular transformation. Trends Genet 1999; 15: 229-35

85 Leonarduzzi G, Scavazza A, Biasi F, Chiarpotto E, Camandola S, Vogel S, Dargel R, Poli G. The lipid peroxidation end product 4-hydroxy-2,3nonenal up-regulates transforming growth factor betal expression in the macrophage lineage: a link between oxidative injury and fibrosclerosis. FASEB J 1997; 11: 851 - 7

86 Reichard JF, Vasiliou V, Petersen DR. Characterization of 4-hydroxy-2nonenal metabolism in stellate cell lines $\mathrm{d}$ from normal and cirrhotic rat liver. Biochim Biophys Acta 2000; 27: 222 - 32

87 Whalen R, Rockey DC, Friedman SL, Boyer TD. Activation of rat heaptic stellate cells leads to loss of glutathione S-transfer and their enzymatic activity against products of oxidative stress. Hepatology 1999; 30: $927-33$

88 Maher JJ, Saito JM, Neuschwander-Tetri BA. Glutathione regulation in rat hepatic stellate cells. Comparative studies in primary culture and in liver injury in vivo. Biochem Pharmacol 1997; 53: 637-41

89 Montosi G, Garuti C, Iannone A, Pietrangelo A. Spatial and temporal dynamics of hepatic stellate cell acitivation during oxidant-stress-induced fibrogenesis. Am J Pathol 1998; 152: 1319-26

90 Maher JJ, Neuschwander-Tetri BA. Manipulation of glutathione stores in rat hepatic stellate cells does not alter collagen synthesis. Hepatology 1997; 26: $618-23$

$91 \mathrm{Kim} \mathrm{KY,} \mathrm{Choi} \mathrm{I,} \mathrm{Kim} \mathrm{SS.} \mathrm{Progression} \mathrm{of} \mathrm{hepatic} \mathrm{stellate} \mathrm{cell} \mathrm{activation} \mathrm{is}$ associated with the level of oxidative stress rather than cytokines during CC14-induced fibrogenesis. Mol Cells 2000; 10: 289-300
92 De Bleser PJ, Xu G, Rombouts K, Rogiers V, Geerts A. Glutathione levels discriminate between oxidative stress and transforming growth factor-beta signaling in activated rat hepatic stellate cells. J Biol Chem 1999; 274: $3881-7$

93 Schuppan D, Koda M, Bauer M, Hahn EG. Fibrosis of liver, pancreas and intestine: common mechanisms and clear targets? Acta GastroEnterol Belgica 2000; 63: 366 - 70

94 Windmeier C, Gressner AM. Pharmacological aspects of pentoxifylline with emphasis on its inhibitory actions on hepatic fibrogenesis. Gen Pharmacol 1997; 29: 181 - 96

95 Ferency P, Dragosics B, Dittrich H, Frank H, Benda L, Lochs H, Meryn S, Base W, Schneider B. Randomized controlled trial of silymarin-treatment in patients with cirrhosis of the liver. J Hepatol 1989; 9: 105 - 13

96 Held Ch. Silymarin bei Hepatopathien. Fibrose-Hemmung unter Praxisbedingungen. Therapiewoche 1992; 42: 1696-701

97 Boigk G, Stroedter L, Herbst H, Waldschmidt J, Riecken E, Schuppan D. Silymarin retards collagen accumulation in early and advanced biliary fibrosis secondary to complete bile duct obliteration in rats. Hepatology 1997; 26: $643-9$

98 Jia JD, Bauer M, Cho JJ, Ruehl M, Milani S, Boigk G, Riecken EO, Schuppan D. Antifibrotic effect of silymarin in rat secondary biliary fibrosis is mediated by downregulation of procollagen alpha 1(I) and TIMP-1. J Hepatol 2001; 35: $392-8$

99 Campos R, Garrido A, Guerra R, Valenzuela A. Silybin dihemisuccinate protects against glutathione depletion and lipid peroxidation induced by acetaminophen on rat liver. Planta Med 1989; 55: 417-9

100 Pietrangelo A, Borella F, Casalgrandi G, Montosi G, Ceccarelli D, Gallesi $\mathrm{D}$, et al. Antioxidant activity of silybin in vivo during chronic iron overload in rats. Gastroenterology 1995; 109: 1941 -9

101 Nan JX, Park EJ, Lee SH, Park PH, Kim JY, Ko G, Sohn DH. Antifibrotic effect of Stephania tetrandra on experimental liver fibrosis induced by bile duct ligation and scission in rats. Arch Pharm Res 2000; 23 : $501-6$

102 Nan JX, Park EJ, Kim HJ, Ko G, Sohn DH. Antifibrotic effects of the methanol extract of Polygonum aviculare in bibrotic rats induced by bile duct ligation and scission. Biol Pharm Bull 2000; 23: 240-3

103 Peres W, Tunon MJ, Collado PS, Herrmann S, Marroni N, GonzalesGallego J. The flavonoid quercetin ameliorates liver damage in rats with biliary obstruction. J Hepatol 2000; 33: 742-50

104 Sakaida I, Matsumura Y, Akiyama S, Hayashi K, Ishige A, Okita K. Herbal medicine Sho-saiko-to (TJ-9) prevents liver fibrosis and enzymealtered lesions in rat liver cirrhosis induced by a choline-deficient $\mathrm{L}-$ amino acid-defined diet. J Hepatol 1998; 28: 298-306

105 Shimizu I, Ma Y-R, Mizobuchi X, Miura T, Nakai Y, Yasuda M, Shiba M, Horie T, Amagaya S, Kawada N, Hori H, Ito S. Effects of Sho-saiko-to, a Jananese herbal medicine, on hepatic fibrosis in rats. Hepatology 1999; 29: $149-60$

106 Ono M, Miyamura M, Kyotani S, Saibara T, Ohnishi S, Nishioka Y. Effects of Sho-saiko-to extract on liver fibrosis in relation to the changes in hydroxyproline and retinoid levels of the liver in rats. J Pharm Pharmacol 1999; 51: 1079-84

107 Hirayama C, Okumura M, Tanikawa K, Yano M, Mizuta M, Ogawa N. A multicenter randomized controlled clinical trial of Sho-saiko-to in chronic active hepatitis. Gastroenterol Jpn 1989; 24: 715-9

108 Shimizu I. Sho-siako-to: Japanese herbal medicine for protection against hepatic fibrosis and carcinoma. J Gastroenterol Hepatol 2000; 15: $84-90$

109 Lieber C, Leo M, Aleynik S, Aleynik M, DiCarli L. Polyenylphosphatidyl-choline decreases alcohol-induced oxidative stress in the baboon. Alcohol Clin Exp Res 1997; 21: 375 -9

110 Turkdogan MK, Agaoglu Z, Yener Z, Sekeroglu R, Akkan HA, Avci ME. The role of antioxidant vitamins ( $\mathrm{C}$ and $\mathrm{E}$ ), selenium and Nigella sativa in the prevention of liver fibrosis and cirrhosis in rabbits: new hopes. Dtsch Tierarztl Wochenschr 2001; 108: 71 -3

111 Jose JK, Kuttan R. Hepatoprotective activity of Emblica officinalis and Chyavanaprash. J Ethnopharmacol 2000; 72: 135-40

112 Park EJ, Nan JX, Kim JY, Kang HC, Choi JH, Lee SJ, Lee BH, Kim SJ, Lee JH, Kim YC, Sohn DH. The ethanol-soluble part of a hot-water extract from Artemisia iwayomogi inhibits liver fibrosis induced by carbon tetrachloride in rats. J Pharm Pharmacol 2000; 52: 875-81

113 Szende B, Timar F, Hargitai B. Olive oil decreases liver damage in rats caused by carbon tetrachloride $\left(\mathrm{CCl}_{4}\right)$. Exp Toxicol Pathol 1994; 46: $355-9$

114 Kawada N, Seki S, Inoue M, Kuroki T. Effect of antioxidants, resveratrol, quercetin, and $\mathrm{N}$-acetylcysteine, on the functions of cultured rat hepatic stellate cells and Kupffer cells. Hepatology 1998; 27: 1265-74 
115 Rice-Evans C. Plant polyphenols: free radical scavengers or chainbreaking antioxidants. Biochem Soc Symp 1995; 61: 103 - 16

116 Osawa T. Protective role of dietary polyphenols in oxidative stress. Mech Ageing Dev 1999; 111: $133-9$

117 Gebhardt R. Antioxidative and protective properties of extracts from leaves of the artischoke (Cynara scolymus L.) against hydroperoxideinduced oxidative stress in cultured rat hepatocytes. Toxicol App Pharmacol 1997; 144: 279-86

118 Fuchs EC, Weyhenmeyer R, Weiner OH. Effects of silibinin and of a synthetic analogue on isolated rat hepatic stellate cells and myofibroblasts. Arzneimittelforschung 1997; 47: $1383-7$

119 Godichaud S, Krisa S, Couronne B, Dubuisson L, Merillon JM, Desmouliere A, Rosenbaum J. Deactivation of cultured human liver myofibroblasts by trans-resveratrol, a grapevine-derived polyphenol. Hepatology 2000; 31: $922-31$

${ }^{120}$ Kayano K, Sakaida I, Uchida K, Okita K. Inhibitory effects of the herbal medicine Shosaiko-to (TJ-9) on cell proliferation and procollagen gene expressions in cultured rat hepatic stellate cells. J Hepato 1998; 29: $642-9$

${ }^{121}$ Ricupero DA, Polkis CF, Risihikof DC, Kuang PP, Goldstein RH. Apigenin decreases expression of the myofibroblast phenotype. FEBS Lett 2001; 506: $15-21$

122 Akiyama T, Ishida J, Nakagawa S, Ogawara H, Watanabe S, Itoh N, Shibuya M, Fukami Y. Genistein, a specific inhibitor of tyrosine-specific protein kinases. J Biol Chem 1987; 262: $5592-5$

${ }^{123}$ Ferriola PC, Cody V, Middleton E Jr. Protein kinase C inhibition by plant flavonoids. Kinetic mechanisms and structure-activity relationships. Biochem Pharmacol 1989; 38: 1617-24

124 Jinsart W, Ternai B, Polya GM. Inhibition of rat liver cyclic AMP-dependent protein kinase by flavonoids. Biol Chem Hoppe Seyler 1992; 373: $205-11$

${ }^{125}$ Walker EH, Pacold ME, Perisic O, Stephens L, Hawkins PT, Wymann MP, Williams RL. Structural determinants of phosphoinositide 3-kinase inhibition by wortmannin, LY29002, quercetin, myricetin, and staurosporine. Mol Cell 2000; 6: 909-19

${ }^{126}$ Gebhardt R. Inhibition of cholesterol biosynthesis in primary cultured rat hepatocytes by artichoke (Cynara scolymus L.) extracts. J Pharmacol Exp Therap 1998; 86: 1 -7

127 Yoshida M, Sakai T, Hosokawa N, Marui N, Matsumoto K, Fujioka A, Nishino H, Aoike A. The effect of quercetin on cell cycle progression and growth of human gastric cancer cells. FEBS Lett 1990; 260: 10-3
${ }^{128}$ Kuo ML, Yang NC. Reversion of v-H-ras-transformed NIH 3T3 cells by apigenin through inhibiting mitogen activated protein kinase and its downstream oncogens. Biochim Biophys Res Commun 1995; 212: $767-75$

${ }^{129}$ Inoue T, Jackson EK. Strong antiproliferative effects of baicalein in cultured rat hepatic stellate cells. Eur J Pharmacol 1999; 378: 129-35

${ }^{130}$ Reeves HL, Dack CL, Peak M, Burt AD, Day CP. Stress-activated protein kinases in the activation of rat hepatic stellate cells in culture. J Hepatol 2000; 32: $465-72$

131 Yoshizumi M, Tsuchiya K, Kirima K, Kyaw M, Suzaki Y, Tamaki T. Quercetin inhibits Shc- and phosphatidylinositol 3-kinase-mediated c-Jun $\mathrm{N}$-terminal kinase activation by angiotensin II in cultured rat aortic smooth muscle cells. Mol Pharmacol 2001; 60: 656-65

132 Morazzoni P, Montalbetti A, Malandrino S, Pifferi G. Comparative pharmacokinetics of silipide and silymarin in rats. Eur J Drug Metab Pharmacokinet 1993; 18: 289-97

${ }^{133}$ Schandalik R, Perucca E. Pharmacokinetics of silybin following oral administration of silipide in patients with extrahepatic biliary obstruction. Drugs Exp Clin Res 1994; 20: $37-42$

${ }^{134}$ Schulz HU, Schurer M, Krumbiegel G, Wachter W, Weyhenmeyer R, Seidel $G$. The solubility and bioequivalence of silymarin preparations. Arzneimittelforschung 1995; 45: 61 -4

${ }^{135}$ Schandalik R, Gatti G, Perucca E. Pharmacokinetics of silybin in bile following administration of silipide and silymarin in cholecystectomy patients. Arzneimittelforschung 1992; 42: 964-8

${ }^{136}$ Akao T, Kawabata K, Yanagisawa E, Ishihara K, Mizuhara Y, Wakui Y, Sakashita Y, Kobashi K. Baicalin, the predominant flavone glucuronide of scutellariae radix, is absorbed from the rat gastrointestinal tract as the aglycone and restored to its original form. J Pharm Pharmacol 2000; 52: $1563-8$

${ }^{137}$ Li C, Homma M, Oka K. Characteristics of delayed excretion of flavonoids in human urine after administration of Sho-saiko-to, a herbal medicine. Biol Pharm Bull 1998; 21: 1251 -7

138 Gläßer G, Graefe EU, Struck F, Veit M, Gebhardt R. Comparison of antioxidative capacities and inhibitory effects on cholesterol biosynthesis of quercetin and potential metabolites. Phytomedicine 2002; 9: 33 40

${ }^{139}$ Casley-Smith JR. The pathophysiology of lymphedema and the action of benzopyrones in reducing it. Lymphology 1988; 21: 190-4 